\title{
The Outrageous Discourse of Psychoanalysis for Present-Day Academic Institutions
}

\author{
Pietro Barbetta \\ Department of Social and Human Sciences, University of Bergamo, Bergamo, Italy \\ Email: barbetta@unibg.it, barbetta@mediacom.it
}

Received 7 February 2015; accepted 12 March 2015; published 16 March 2015

Copyright (C) 2015 by author and Scientific Research Publishing Inc.

This work is licensed under the Creative Commons Attribution International License (CC BY). http://creativecommons.org/licenses/by/4.0/

c) (i) Open Access

\begin{abstract}
In the following essay I'm going to take a radical position concerning the tendency to eliminate psychoanalysis from the European Academic field and the failure of psychoanalysts and relational therapists to defend psychoanalysis from such aggression. My question is why in Italy-just to make a local example, which I am involved in-different kinds of psychoanalytical traditions are not able to defend themselves from this attack while in France, for another example, all the different branches of relational therapies have been able to unite in making a common effort to take a position for psychoanalysis. One of the main problems, in my opinion, concerns the constitutive marginality of psychoanalysis in relation to Academic Institutions. In my way of writing, I will use psychoanalysis, with " $P$ " in capital character, when referred to Academia, and psychoanalysis, with no capital character, when referred to clinical practice.
\end{abstract}

\section{Keywords}

Psychoanalysis, Academy, Transmission, Subject, Relationship, Epistemology, Ontology

\section{The Constitutive Marginality of Psychoanalytical Discourse in the University}

University is, by definition, the locus where knowledge is transmitted. What does it mean when we are talking about the transmissibility of psychoanalysis?

"Transmissibility" is a dispositional term [1]; it means that in certain circumstances, something works; something has a function, like a match that, if scratched on a rough plane, burns. In that case we'll say that the match is flammable.

In descriptive statistics, for example, we could make an analogy between "transmissible" and "flammable". In the circumstances of clear explanation by the teacher and the regular exercise by the student, descriptive (and probably a large part of inferential) statistics are transmissible. 
Is psychoanalysis transmissible in the same sense? I do not think so. Are there circumstances in which psychoanalysis is transmissible? In my view, the answer is yes, though not in traditional cognitive terms.

Is contemporary academia the way to transmit psychoanalysis? The answer is of course no; never it is widely known that it is not enough to teach psychoanalysis ex cathedra in order to learn psychoanalysis. It is well known that psychoanalysis is, primarily, a kind of relationship between the subject participant in analysis (in Lacanian [2] terms "the analysant", but I prefer to use "subject participant in analysis", referring to Elvio Fachinelli's proposal [3]), and the analyst. In the modern university, this kind of training is unthinkable for a big part of the academy, and even for some of the psychoanalytical mainstream. For Lacanians, for example, it is a constitutive condition of the "Discourse of the University" - the second of the four Lacanian discourses [4], to be separated from the "Discourse of the Analyst". The first one concerns the "big other", and the second one concerns the "little other" [2].

Nevertheless in some university there is the subject/topic and the exam of psychoanalysis.

In Italy they call it Dynamic Psychology, which is not exactly the same. In other countries, for example at Saint Denis University in Paris, there is an entire course on (Lacanian [sic!]) psychoanalysis. I have personally been engaged in it as Maitre de Recherche for a Doctoral Dissertation on Depression in Psychoanalysis. Where there is, as in such circumstances, an academic department or a course on psychoanalysis, what does it mean?

Trying to answer this question is complicated as solving a paradox.

Let us go back to the Paris example: who was the subject who was going to discuss her PhD dissertation on psychoanalysis at Saint Denis? The PhD student was a trained psychoanalyst, more or less my age. If we take this example as paradigmatic, we should conclude that in order to learn psychoanalysis at university, one should be already a trained psychoanalyst—an interesting paradox.

Such a paradox concerns the responsibility of the subject as psychoanalyst. Psychoanalysis seems to be something that you learn and teach at the same time, not just a cognitive experience, not just a doctrinaire institution, not something that you learn step by step from books or explanations. If this is necessary, the present situation is far from ideal. I can learn psychotherapy from my student when I teach in a school of psychotherapy, discussing a clinical case, observing a sequence of therapy, and listening to a trainee's dream during a session. It is the same as I learn psychoanalysis from the ongoing narrative of a dream, during a usual session.

Other examples show the use of psychoanalysis in academy as a part of a program of teaching, investigation and social intervention: there are several universities in the world that are working on psychoanalysis as an important way of dealing with institutional processes. Let's take a couple of examples that I know from Rio de Janeiro:

The Instituto de Medicina Social da Universidade de Estado do Rio de Janeiro (UERJ) is an academic area where psychoanalysts, medical doctors and philosophers are working together around the argument of Public Health—-they call it Saudade Pubilca. In 2006, for example, this group of scholars organized an International Conference concerning the New Forms of Subjectivation in Western Society.

The second example is the Child Psychiatric Unit of the Hospital at the Universidade Federal do Rio de Janeiro (UFRJ), where pediatrician, child psychiatrists, psychoanalysts and family therapist are working together in programs of investigation and intervention on marginality with children and adolescents. Among the sources of inspiration of these researchers, there is the psychiatric Italian experience of the seventies [5], the institutional therapy of Jean Oury and Felix Guattari [6] at La Borde, and other experiences in Latino America.

These are just two examples of useful uses of psychoanalysis as a method of training, investigation and intervention, and I am sure there are many others.

From one hand, in Paris, I saw a PhD program for trained psychoanalysts, and from the other, in Rio, I saw psychoanalysis (and other forms of relational therapy, as family therapy) applied to the social field. In both cases, the experience of psychoanalysis is something that goes far beyond academy.

In my personal experience, I entered as a researcher at the university when I was 44 , after extensive private and public clinical work in a Child Psychiatric Unit. I was under analysis with three different psychoanalysts all along many years, and I do not think at my personal analysis as something that ended up. Of course some people may not be able to agree with this. Maybe it is not the case for strategic or behavioral therapy, but in psychoanalysis, or, more in general, in relational therapy, it's crucial. I know my position risks being biased towards the idea that, in order to teach what we call generically "clinical psychology", one has to work for several years on the field, and make clinical experiences; one has to have other experiences, for a long period of her/his own life, outside the academy. This is the outrageous discourse of psychoanalysis for present-day academic way of think- 
ing about what is an academic career.

\section{The Subject in Psychoanalysis}

I believe psychoanalysis is, above all, a kind of relationship. Consequently there is no way of becoming a psychoanalyst or a relational therapist just by studying psychoanalysis as a cognitive subject. The irony of the word "subject" in English is that it means both to the field of study, and the most important figure in psychoanalysis. Nevertheless in psychoanalysis the subject is always in relation to the other.

This allows me to say that the subject in psychoanalysis, as a relationship, differs from the subject "Psychoanalysis” (Dynamic or Clinic Psychology) as a cognitive topic to be learned. The subject, as relationship, is eccentric to the subject, as a topic, in psychoanalysis: de te fabula narratur ${ }^{1}$.

From here on I will distinguish “subject/relationship”- the word designating the subject who attends analysis —from "subject/topic" - the word designating the cognitive transmission of something (Psychoanalysis, History, Philosophy, Statistics, Hairdressing, Whatever). I mean that a student who studies Freud, Jung, Klein, etc. can be super prepared, she/he becomes an Ego trained in the cognitive sense, all maxima cum laude. But the subject/relationship lies elsewhere, it exceeds her/his cognitive expertise.

There are different ideas concerning Psychoanalysis as a topic. Some handbooks contemplate just the "relational object" theory, and the "pulsional” theory, others contemplate Analytical Psychology (Jung), but exclude Ego-Psychology (the dominant North American idea of what psychoanalysis is), and so on. I have my own position on the teaching of Psychoanalysis and Dynamic Psychology, but I strongly believe in the freedom of teaching, so I am not recommending anyone to do what I do, as I consider my colleagues sufficiently "mature”.

Now, I come to another important issue, and the question, in English language, is particularly meaningful: Can ONE teach Psychoanalysis without taking a position? Is Psychoanalysis something which can be taught sine ira et studio [7]? Or does any statement coming from psychoanalysis originate with the subject/relationship? Should the teacher of Psychoanalysis (or Dynamic Psychology, if you prefer) be a subject/relationship who practices psychoanalysis or relational psychotherapy her/himself? Should she/he have had personal analysis her/himself at least once if not more? Those are all questions which are much more important, in my view, than having published articles here and there in some kind of indexed journal.

Silvia Vegetti Finzi [8] and Elvio Fachinelli [9] have written that psychoanalysis is a subversion of knowledge, Christopher Bollas [10] writes that the Freudian couple is there when the unconscious of the person who attends the analysis touches the unconscious of the analyst. All this has little to do with traditional conceptions of theory. Theory in psychoanalysis is theory in relational practice, i.e. psychotherapy. What does it mean? Let me try to answer this way, quoting Freud.

In the $6^{\text {th }}$ Chapter of The Interpretation of Dreams Freud writes:

Thus I perceive the nature of the relation between the dream-content and dream-thoughts: not only are the elements of the dream determined several times over by the dream-thoughts, but the individual dream-thoughts are represented in the dream by several elements.

Starting from a content of the dream, the path of the association leads to a number of dream-thoughts; and from a single dream-thought to several elements of the dream [11].

This is what Freud calls “over-determination”. Let me give you two observations concerning this quotation by Freud.

First: Let us consider Freud's style here: he writes “I perceive the nature, etc.”, the subject Freud writes about his own perception, coming from his own self-analysis and the psychoanalytical experience coming from his own clinical practice of the talking cure. It is not an idiosyncratic experience, it is a relational experience he has with the dreamer and the dreams, something that has a particular kind of quality, an evanescent process, an evocative experience, coming from an ecstatic position. In a few words, something that the subject/relationship enacts, which does not exist anywhere outside the session room. But, at the same time, something that becomes a social experience in the very moment of the ongoing recounting of it in the presence of the Other, the "ear of the Other”, as Jaques Derrida writes [12]. Which means: who is the author of the analysis? Is the therapist the author of the therapy? Are the clinical cases, about which the therapist writes, her/his own property? Or the therapy emanates multiple points of observation, as, just to give an example, in Dora's case: First of all Ida Bauer's refusal to continue the analysis, Freud's publication, Ferenczi observations, and on and on, like Billig,

\footnotetext{
${ }^{1}$ Latin phrase meaning, more or less “I’m talking to you”.
} 
Mahony and many, many others [13]-[16].

Second: in Freud's sentence quoted above, the elements of the dream are over determined by the dream thoughts and the dream thoughts are over determined by the elements of the dream. What does it mean? Could, or should, this sentence have any clear meaning? Interpretation here is far from being the reduction, element by element, from one set- the elements of the dream-to another-the dream thoughts. Those two parts of the dream narrative, elements and thoughts, are, strictly speaking, in term of logic, proper classes, i.e. classes that are not sets because they are too imprecisely specified to be sets [17].

How to learn in practice to deal with this fuzzy process that brings you to the singularity of the event, with no direct experience of the practice of psychotherapy?

You can give at least an idea to your students, dealing, in class, with clinical cases, dreams, conversations. You can take some example from literature, ethnography. But, above all, you have to deal with the origin of psychoanalysis. In my view, for example, it is completely ridiculous to tell the students things like "Psychoanalysis is valid for Hysteria, Systemic Therapy for Anorexia, Cognitive Therapy for Phobia, etc.”. I find it a kind of functionalist stupidity.

What should we do with psychoanalysis when faced with a new young student who knows nothing about the subject. I mean the living subject, who belongs to history, who is moved by art and literature, who belongs to some kind of social class, who is diagnosed, and so on. In my opinion the psychoanalytical lesson consists, first of all, of giving the student an historical framework of the ages and the Zeitgeist in which Freud and his followers have been working (Jewish tradition, Post-Romantic age, crisis of European sciences, continental philosophy, modern literature), the marginal position they had, and the subversion they carried out, in relation to medical discourses, the outrageous position for Academia because of the different epistemology and ontology proposed by psychoanalysis.

\section{Epistemological and Ontological Issues}

This has to do with a philosophical assumption: the incommensurability between origin and function. As in Nietzsche [18]:

No matter how well we have understood the usefulness of some physiological organ or other (or a legal institution, a social custom, a political practice, some style in art or in religious cults), we have not, in that process, grasped anything about its origin —no matter how uncomfortable and unpleasant this may sound in elderly ears. From time immemorial people have believed that in demonstrable purposes, the usefulness of a thing, a form, or an institution, they could understand the reasons it came into existence- - the eye as something made to see, the hand as something made to grasp (p. 12. Translated by Ian Johnston).

What Nietzsche writes, in On the Genealogy of Morals, became in Foucault's researches [19], starting from the Sixties of the $20^{\text {th }}$ Century, a Method of investigation, i.e. the Genealogical Method. Unlike Foucault position towards Psychoanalysis, Foucauldian Method opens the possibility for psychoanalysis to investigate social world in a different way, for example in new researches on gender, culture, disability, anthropological, social history studies that never existed before. In an era of cultural restoration, this is the main reason why teaching psychoanalysis in the new Academia is a difficult, perhaps impossible, task. This is the reason why the discourse of psychoanalysis is outrageous for present-day Academy.

How can the "new academic" discourses accept the kind of conception that Freud, referring to the interpretation (Deutung) of dreams, gave when he wrote this words:

We have given equal attention, in the interpretation of dreams, to every nuance of verbal expression found in them; indeed, whenever we were confronted by a senseless or insufficient wording, as though we had failed to translate the dream into the proper version, we have respected even these defects of expression. In brief, what other writers have regarded as arbitrary improvisations, concocted hastily to avoid confusion, we have treated like a sacred text. (p. 10)

David Meghnagi [20], one of the psychoanalysts who write on the more relevant issues concerning psychoanalysis at the present time, claims, in Il padre e la legge. Freud e l'ebraismo:

Via an operation that radically upset medical thinking from within, and with an argumentation that must have been disturbing to those academics who would have preferred to let it pass in silence, dreams and symptoms took the place that in the Jewish tradition is occupied by sacred texts (ivi, p. 175, translation from Italian by Michael Paysden). 
How important is it for regular students in current departments of psychology to learn about analyzing dreams, or conversation in therapy, in terms of a sacred test in the Jewish tradition (which is different from analyzing texts in the Christian tradition)? Is that transmissible? And in which way? I think partially, even not entirely, transmitted, just to give them an idea about what is going to be their future life if they chose psychoanalysis as a job.

Sometimes I use the "Conversational Analysis" methodology by Aron Cicourel [21] and Harold Garfinkel [22] because of the accuracy in the signs denoting pauses, voices overlapping, and other tiny details. Is that of any use in a place surrounded by a totally different kind of epistemology like the present clinical Academy? Where the mainstream consists in talking about functional families, functional disorder, test standardization (all important things, I mean), how can a student become interested in a 5 second pause in this specific ongoing conversation, or an anagram of a word which comes from this specific dream account? Is there a way where we can reconnect the subject/topic with the subject/relation? In those moments I think it would be better to leave psychoanalysis outside of an Academy in which test standardization and medical discourses are completely hegemonic. An Academy in which psychiatric epidemiology and clinical psychology are in the process of becoming the same subject.

\section{Conclusions}

It would be easy to conclude that psychoanalysis is the realm of "mere opinions", and certainly this is a facile ideological statement made by academics who believe that science is doing "collective" work in line with the old/new positivistic principles: only quantitative methods, standardization, evidence-based diagnosis. And this is also a "good" enterprise, in which the young students make the dirty job to put data in the SPSS program and the elder scholars sign the paper, and we are all content because career goes on.

Does the field of psychology still exist or simply the new field of neuro-psychology? In a time in which neurologists are shifting their own view from individuals to relationships, the stupidity prevails in psychology that people have, or not, mirror neurons, as if mirror neurons would be entities disconnected from the relationship with the other.

Is there still, in the dominant discourse of clinical psychology, the idea of Personhood, responsiveness, accountability, responsibility, or is the mainstream of our ages Brainhood? Is Brainhood substituting Personhood in the new "scientific imposition"? Is it a scientific statement to say that relational or social episodes are essentially due to neurotransmitters? Cathrine Malabou [23] wrote that the new metaphor of the Brain as a matrix of Society is hegemonic in the new social discourses. Maybe she is wrong in general, although she is certainly right with regard to the mainstream of psychology at the present time.

Is research into clinical cases, the analysis of transfert, and the description of a singular process in family/ group dynamics just "mere opinion"? What has happened to the old tradition of psychoanalytic research (from Melanie Klein's children to Adorno's Authoritarian Personality, from Otto Rank’s Döppelganger, to Bion’s groups, etc.)? How should psychoanalysis be protected from the brutal aggression of books like the many black books of psychoanalysis? Why, in France, starting with Academics like Elisabeth Roudinesco [24], is there a proud defense of our field and way of working and investigating, while in Italy and in the US, for example, the few voices defending psychoanalysis come from Academic outsiders?

The gap between psychoanalysis and academia is going to become wider and wider. I think we need to completely rethink our universities, our departments, our systems of training and evaluating students to review our position in the field of clinical/dynamic psychology in order to maintain psychoanalysis and relational psychotherapy within the dominion of human and social sciences.

In the future years of my academic life, I myself will be engaged, possibly alone, in following the Ulpian principle of Honestae Vivere, and the ancient tradition, renewed by Michel Foucault [25], of exercising the Parrhesia (in English Parrhesia could be translated as "free speech", in Italian "parlar franco") with my colleagues, my students and the academic powers-that-be. This is the reason, in my view, which makes psychoanalysis outrageous for the academic discourse in present days.

\section{References}

[1] Goodman, N. (1983) Fact, Fiction, and Forecast. Harvard University Press, Cambridge.

[2] Evans, D. (1996) An Introductory Dictionary of Lacanian Psychoanalysis. Routledge, London. 
[3] Fachinelli, E. (1983) Claustrofilia. Adelphi, Milano.

[4] Lacan, J. (1991) Le Seminaire, Livre 17, l’envers de la psychanalyse. Seuil, Paris.

[5] Basaglia, F. (1987) Psychiatry inside Out: Selected Writings of Franco Basaglia. Columbia University Press, New York.

[6] Guattari, F. (2012) De Leros à La Borde. Ligne, Paris.

[7] Weber, M. (1922) “Wissenschaft als Beruf”, Gesammlte Aufsaetze zur Wissenschaftslehre. Gerth, H.H. and Wright Mills, C., Trans. and Eds. (1946) From Max Weber: Essays in Sociology. Oxford University Press, New York.

[8] Vegetti Finzi, S. (1990) Storia della psicoanalisi. Mondadori, Milano.

[9] Fachinelli, E. (2012) Su Freud. Adlephi, Milano.

[10] Bollas, C. (2008) The Evocative Object World. Routledge, London.

[11] Freud, S. (2010) The Interpretation of Dreams: The Illustrated Edition. Sterling Press, Salt Lake City.

[12] Derrida, J. (1988) The Ear of the Other: Otobiography, Transference, Translation. The University of Nebraska Press, Lincoln.

[13] Freud, S. (1905) Fragments of an Analysis of a Case of Hysteria. Standard Edition, Vol. 7, Vintage, London.

[14] Ferenczi, S. (1995) The Clinical Diary of Sándor Ferenczi. Harvard University Press, Cambridge.

[15] Mahony, P.J. (1986) Freud’s Dora. Yale University Press, New Haven and London.

[16] Billig, M. (1999) Freudian Repression: Conversation Creating the Unconscious. Cambridge University Press, London.

[17] Vopěnka, P. (1989) Introduction to Mathematics in the Alternative Set Theory. Alfa, Bratislava.

[18] Nietzsche, F. (1988) Zur Genealogie der Moral. Reclam, Leipzig.

[19] Foucault, M. (1980) Nietzsche, Genealogy, History. In: Bouchard, D.F., Ed., Language, Counter-Memory, Practice: Selected Essays and Interviews, Cornell University Press, Ithaca, 145-172.

[20] Meghnagi, D. (2004) Il padre e la legge. Freud e l'ebraismo. Marsilio, Venezia.

[21] Cicourel, A.V. (1973) Cognitive Sociology: Language and Meaning in Social Interaction. Penguin, New York.

[22] Garfinkel, H. (1967) Studies in Ethnomethodology. Prentice Hall, Englewood Cliffs.

[23] Malabou, C. (2008) What Should We Do with Our Brain? Fordham University Press, New York.

[24] Roudinesco, E. (2010) Mais pourquoi tant de haine? Seuil, Paris.

[25] Foucault, M. (1999) The Practice of Parrhesia. In: Pearson, J., Ed., Discourse and Truth: The Problematization of Parrhesia, Foucault, Digital Archive. http://foucault.info/system/files/pdf/DiscourseAndTruth_MichelFoucault_1983_0.pdf 